\title{
AMS RADIOCARBON DATING OF WOOD SAMPLES FROM THE ANGKOR MONUMENTS, CAMBODIA
}

\author{
E Uchida $^{1,2} \bullet \mathrm{O} \mathrm{Cunin}^{3} \bullet \mathrm{I} \mathrm{Shimoda}^{4} \bullet \mathrm{Y} \mathrm{Takubo}^{1} \bullet \mathrm{T} \mathrm{Nakagawa}^{4}$
}

ABSTRACT. In the Angkor monuments of Cambodia, pieces of wood remain (as head frames of doorways, crossbeams, ceiling boards, etc.) in the following 8 monuments: Bakong, Lolei, Baksei Chamkrong, North Khleang, Angkor Wat, Banteay Kdei, Bayon, and Gates of Angkor Thom. Accelerator mass spectrometry (AMS) radiocarbon dating carried out on 15 wood samples collected from the above 8 monuments revealed that most of the wood samples are original, except for the head frame of a doorway in Baksei Chamkrong, the ceiling boards in the northwest tower, and a crossbeam with pivot hole in the southwest tower of the Inner Gallery of Angkor Wat. The ${ }^{14} \mathrm{C}$ age for the head frame of a doorway in the inner wall under the central tower of North Khleang supports the hypothesis that the inner walls are additions from a later period.

\section{INTRODUCTION}

The Angkor monuments are Hindu and Buddhist temples built from the 9th to 13th centuries AD. In the Angkor monuments - in addition to the main construction materials of sandstone, laterite, and brick - wood was also used as roofs, head frames of doorways, beams, etc. All wood in the roofs has already rotted away, whereas wood inside the buildings, such as head frames of doorways and beams, remained in several monuments. We question whether the inside wood is original or not. In this study, accelerator mass spectrometry (AMS) radiocarbon dating was carried out for the remaining wood samples in the Angkor monuments. There are few studies on the ${ }^{14} \mathrm{C}$ dating of wood samples in the Angkor monuments. Zoppi et al. (2004) obtained the ${ }^{14} \mathrm{C}$ age for a pillar in the wooden gallery on the Terrace of the Leper King. Uchida et al. (2005) carried out ${ }^{14} \mathrm{C}$ dating for charcoal fragments found at Prasat Suor Prat and revealed that Prasat Suor Prat was constructed in the Angkor Wat period, not in the Bayon period as previously thought.

\section{MEASUREMENT OF RADIOCARBON AGE}

For the 15 wood samples mentioned in the following section, pretreatment and ${ }^{14} \mathrm{C}$ dating measurements were performed by Paleo Labo Co., Ltd. (Kobayashi et al. 2007). After ultrasonic washing in boiling water, the wood samples were treated with the AAA (acid-alkali-acid) method. The wood samples were then burned into carbon dioxide, and the carbon dioxide was reduced to obtain graphite. The graphite samples were measured for ${ }^{12} \mathrm{C},{ }^{13} \mathrm{C}$, and ${ }^{14} \mathrm{C}$ contents using the Paleo Labo compact AMS system (National Electrostatics Corp., Middleton, Wisconsin, USA). After correction for isotopic fractionation, the obtained ${ }^{14} \mathrm{C}$ ages were calibrated using the software OxCal 3.10 (Bronk Ramsey 1995, 2001) and the IntCal04 calibration curve (Reimer et al. 2004).

\section{WOOD SAMPLES, DATING RESULTS, AND CONSIDERATION}

The presence of remnant wood was confirmed in the following 8 monuments: Bakong, Lolei, Baksei Chamkrong, North Khleang, Angkor Wat, Banteay Kdei, Bayon, and Gates of Angkor Thom. Fifteen wood samples were taken from the 8 monuments for ${ }^{14} \mathrm{C}$ dating (Table 1). The samples were collected from the surface of the wood. Tree rings could not be counted accurately because both ends of the wood samples are covered by stones.

\footnotetext{
${ }^{1}$ Dept. of Resources and Environmental Engineering, Waseda University, Ohkubo 3-4-1, Shinjuku, Tokyo 169-8555, Japan. ${ }^{2}$ Corresponding author. Email: weuchida@ waseda.jp.

${ }^{3}$ Centre for Khmer Studies, PO Box 9380 Wat Damnak, Siem Reap, Cambodia.

${ }^{4}$ Dept. of Architecture, Waseda University, Ohkubo 3-4-1, Shinjuku, Tokyo 169-8555, Japan.
} 


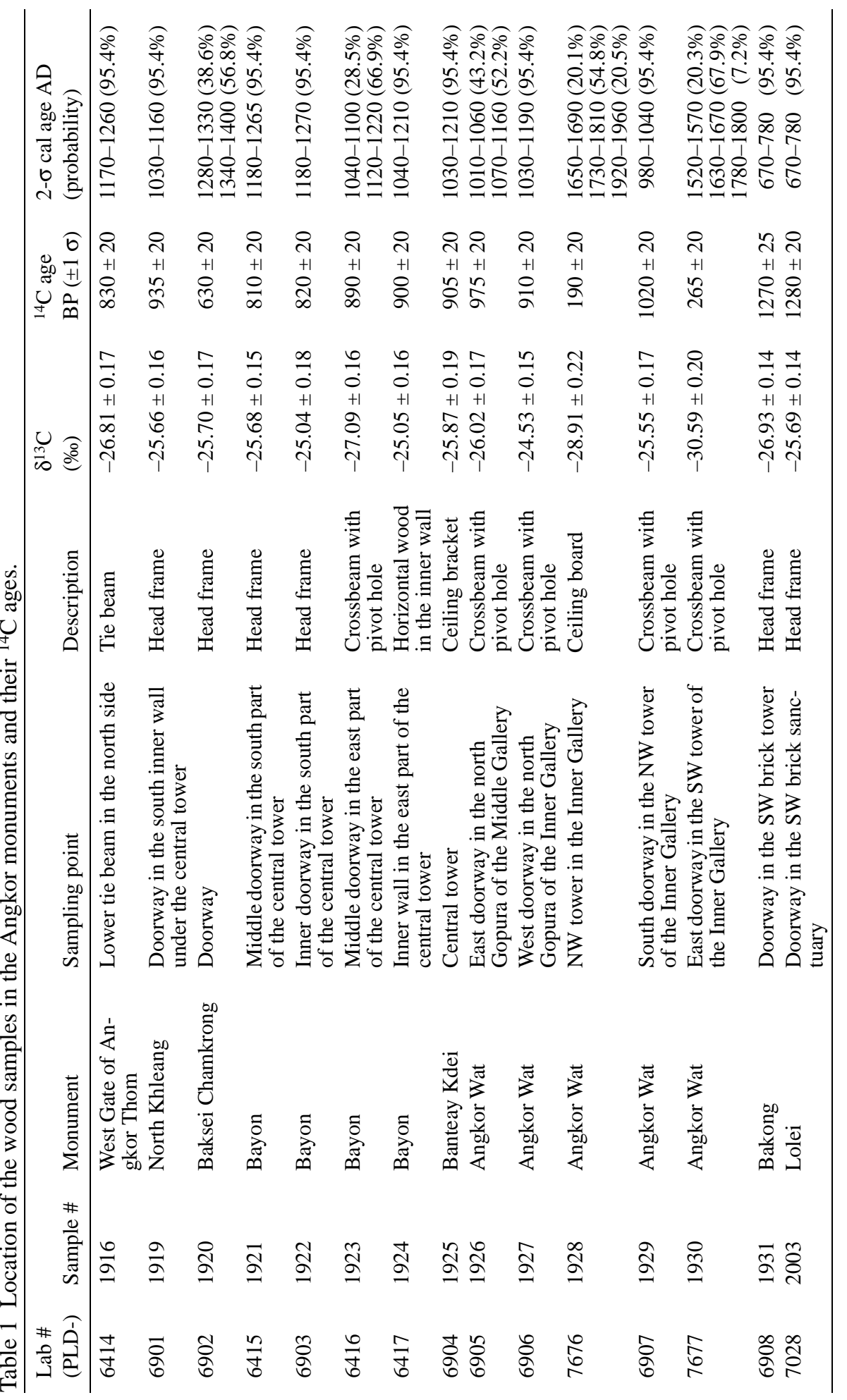




\section{Bakong}

According to its inscription, Bakong was built in AD 881. It is comprised of a platform shaped like a stepped pyramid and topped with a central sanctuary and the surrounding brick buildings. Glaize (1944) and Boisselier (1952) concluded that the present central sanctuary was built in the Angkor Wat period (first half of the 12th century). On the other hand, based on the magnetic susceptibility of the sandstone and other characteristics, Uchida et al. $(1998,2007)$ suggested that the present central sanctuary was probably constructed at the end of the Bayon period (end of the 12th century to the early 13th century). One wooden head frame of a doorway remains in the brick tower situated in the southwest of the stepped-pyramid-shaped platform topped by the central sanctuary. A wood sample was taken from the head frame (sample 1931, Figure 1). Its calibrated calendar year range is AD 670-780 (2 $\sigma)$. The construction age of Bakong, not including the central sanctuary, is AD 881 according to its inscription, very similar to the ${ }^{14} \mathrm{C}$ age obtained.
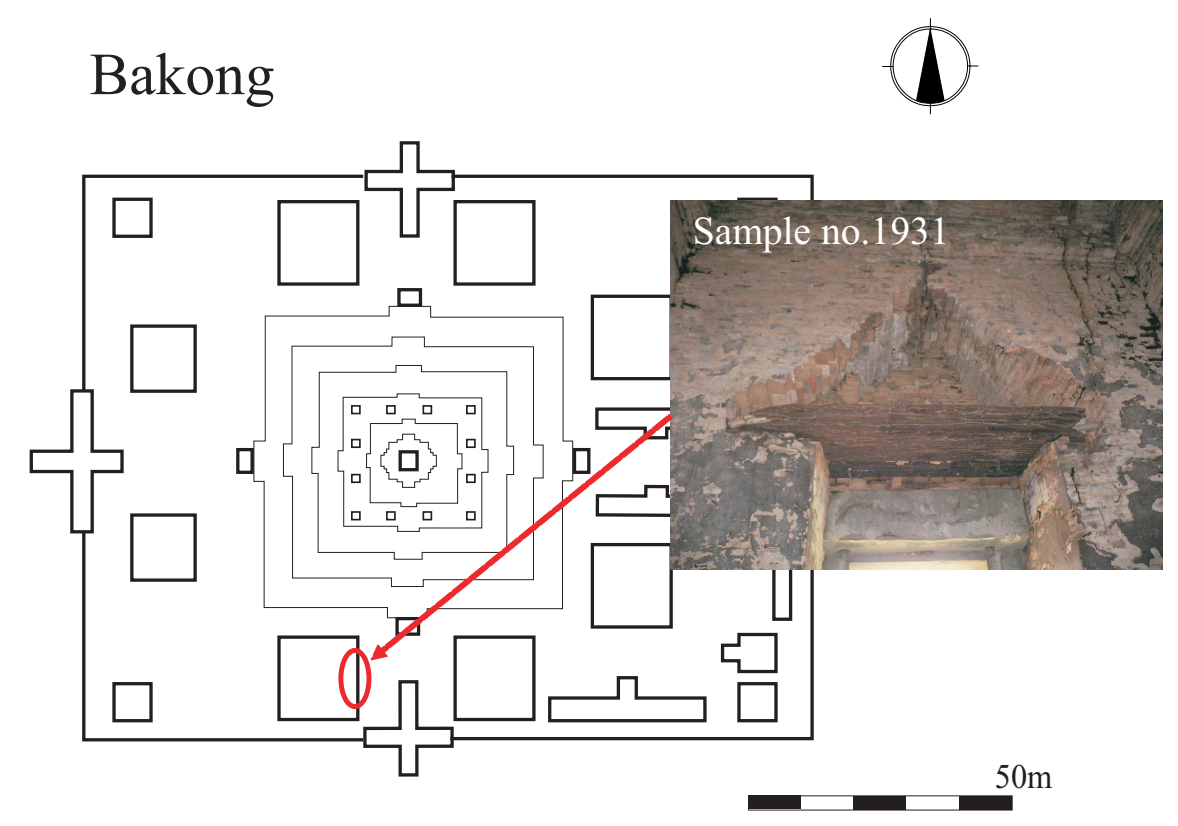

Figure 1 Location of wood sample 1931, taken from a head frame of a doorway in the SW brick tower in Bakong.

\section{Lolei}

Situated in the center of the Indratataka baray (an artificial body of water), Lolei is believed to have been built in AD 893. Lolei was originally composed of 6 brick sanctuaries, but at present only 4 sanctuaries remain. Wood samples were taken from head frames of doorways in the NE and SW sanctuaries. A wood fragment was collected from the head frame of the SW sanctuary (sample 2003, Figure 2). The ${ }^{14} \mathrm{C}$ age for the Lolei wood ranges from $\mathrm{AD} 670-780(2 \sigma)$, the same as for Bakong. The construction age of Lolei is estimated as $\mathrm{AD} 893$, which is concordant with the ${ }^{14} \mathrm{C}$ date obtained.

\section{Baksei Chamkrong}

Estimated to have been built in the mid-10th century, Baksei Chamkrong was dedicated in AD 948. It is comprised of a small brick sanctuary situated on a stepped-pyramid-shaped platform made of 


\section{Lolei}

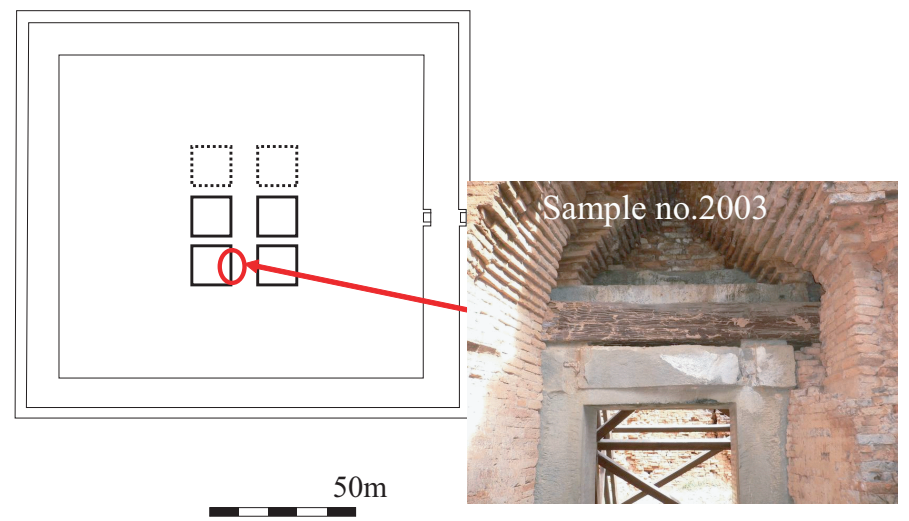

Figure 2 Location of wood sample 2003, taken from a head frame of a doorway in the SW brick sanctuary of Lolei.

laterite. The sampled wood fragment is from a head frame of a doorway (sample 1920, Figure 3). It is considerably decayed and thus was easily detached from the door. The ${ }^{14} \mathrm{C}$ age range for the wood of Baksei Chamkrong is AD 1280-1400 (2 $\sigma), 300$ to 400 yr younger than the previously estimated construction age (mid-10th century). This suggests that the wooden head frame is not original but instead was added after the 14th century.

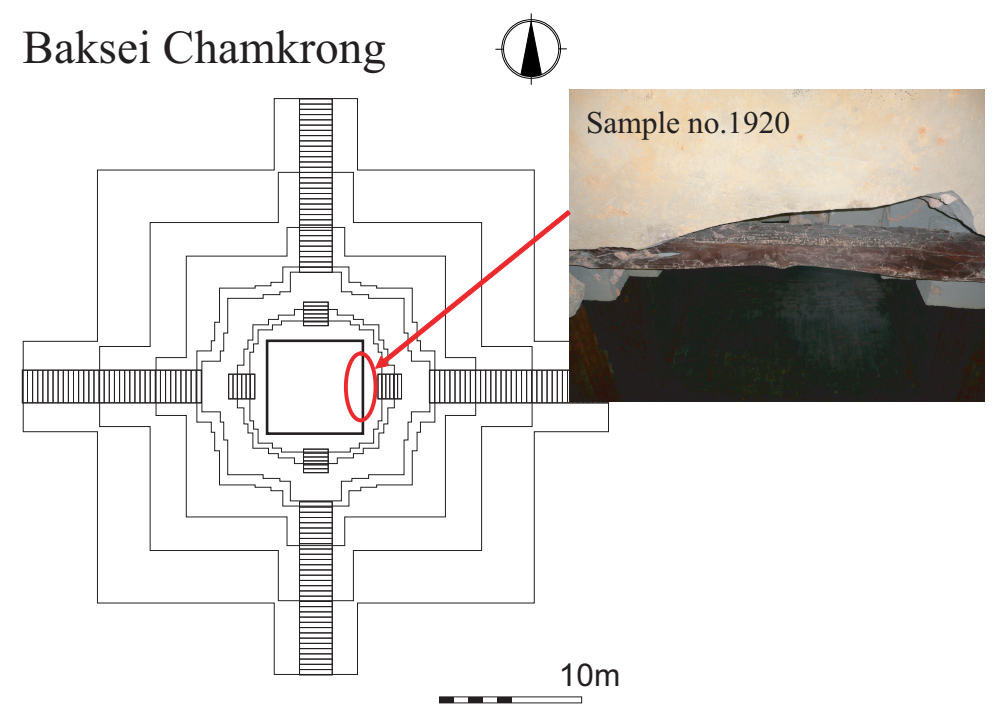

Figure 3 Location of wood sample 1920, taken from a head frame of a doorway in Baksei Chamkrong.

\section{North Khleang}

North Khleang is thought to have been constructed from the end of the 10th century to the beginning of the 11th century. However, Dumarçay (1998) believes the central tower is an addition from the 
end of the Bayon period. This contention is also supported by the magnetic susceptibility and shape of the sandstones and the existence of reused sandstones (Uchida et al. 1998, 2007). Wood was used in the head frames of doorways in the north and south inner walls supporting the central tower. One wood sample was taken from the head frame of the south inner wall (sample 1919, Figure 4).

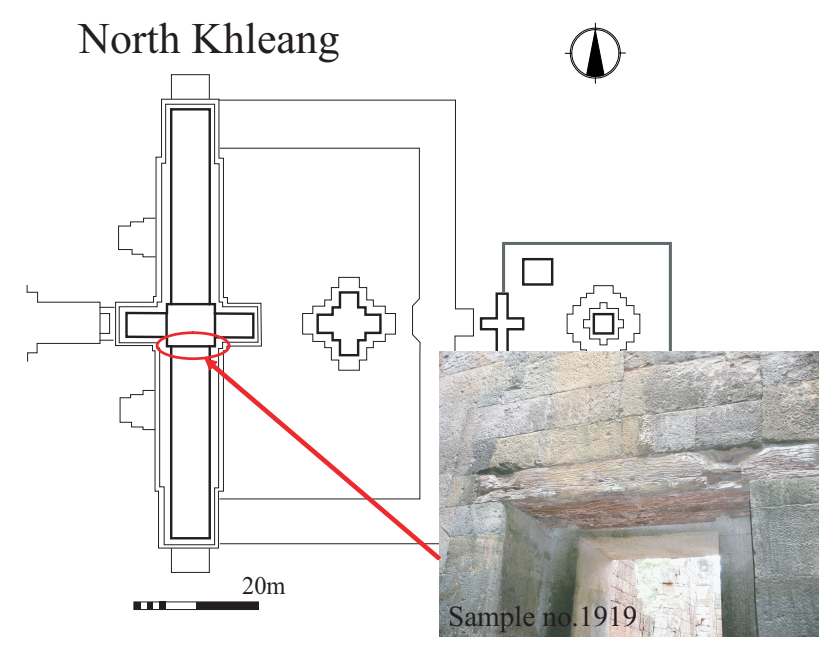

Figure 4 Location of sample 1919, taken from ahead frame of a doorway in the south inner wall under the central tower of North Khleang.

Sample 1919 was dated to AD 1030-1160 (2 $\sigma)$. This seems to contradict the previous estimation of the construction age for the main part of North Khleang (end of 10th century to beginning of 11th century). The place where the wood sample was collected is an addition from the early 13th century. The obtained ${ }^{14} \mathrm{C}$ age does not contradict this fact; rather, the ${ }^{14} \mathrm{C}$ age supports that the inner walls under the central tower are not original but are later additions.

\section{Angkor Wat}

Angkor Wat is thought to have been built from AD 1113 to 1150, during the reign of Suryavarman II. Wood remains in several places as crossbeams with pivot holes in the doorways and as ceiling boards in the Middle and Inner Galleries. In this study, wood fragments were collected from 4 crossbeams (samples 1926, 1927, 1929, and 1930) and 1 ceiling board (sample 1928) (Figure 5). The crossbeams, except for in the SW tower of the Inner Gallery (sample 1930), have decoration on the surface. The crossbeam in the SW tower of the Inner Gallery is small in size and looks fresh compared with the other crossbeams.

The ${ }^{14} \mathrm{C}$ age ranges $(2 \sigma)$ for the 3 wood samples $(1926,1927$, and 1929) taken from the crossbeams with pivot holes are AD 1010-1160, 1030-1190, and 980-1040, respectively. Considering that the IntCal04 calibration curve shows severe fluctuation around AD 1020 to 1160 and also that Angkor Wat is believed to have been built from AD 1113 to 1150, the above 3 samples seem to be original. However, the ceiling board (sample 1928) of the NW tower of the Inner Gallery and the crossbeam with pivot hole (sample 1930) of the SW tower of the Inner Gallery gave ${ }^{14} \mathrm{C}$ age ranges $(2 \sigma)$ of $\mathrm{AD}$ 1650-1960 and 1520-1800, respectively. These results clearly suggest that both samples are not original. The crossbeam with pivot hole of the SW tower of the Inner Gallery is small in size and has no decoration, which is different from the characteristics of the other crossbeams. 


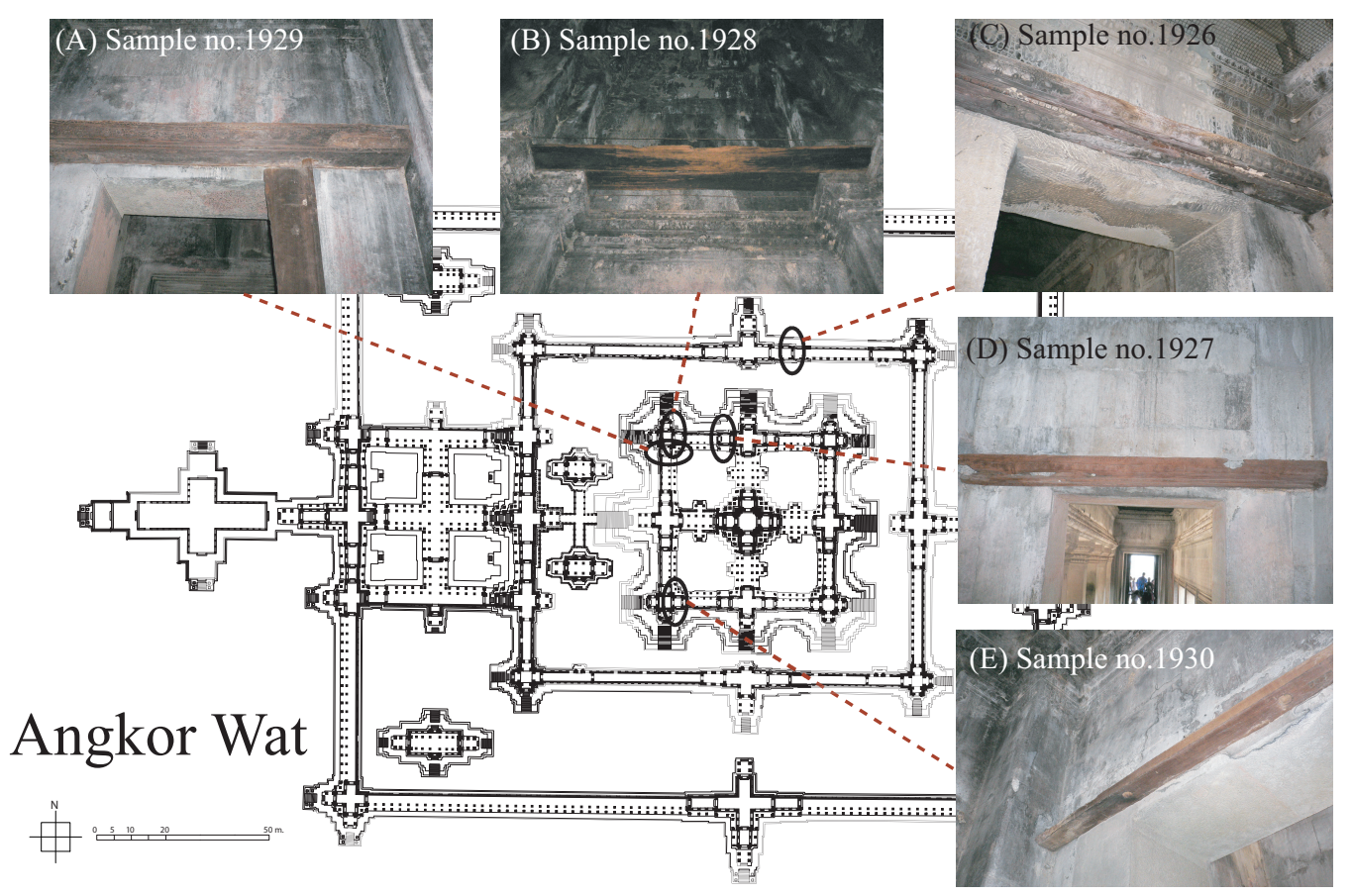

Figure 5 Location of wood samples in Angkor Wat: (A) a crossbeam with pivot hole in the south doorway of the NW tower of the Inner Gallery; (B) a ceiling board in the NW tower in the Inner Gallery; (C) a crossbeam with pivot hole in the east doorway in the north Gopura of the Middle Gallery; (D) a crossbeam with pivot hole in the west doorway in the north Gopura of the Inner Gallery, and (E) a crossbeam with pivot hole in the east doorway in the SW tower of the Inner Gallery.

\section{Banteay Kdei}

Banteay Kdei is believed to have been built from the end of the 12th century to the early 13th century. Wood remains as ceiling brackets in the central tower despite intense decay (sample 1925, Figure 6).

\section{Banteay Kdei}

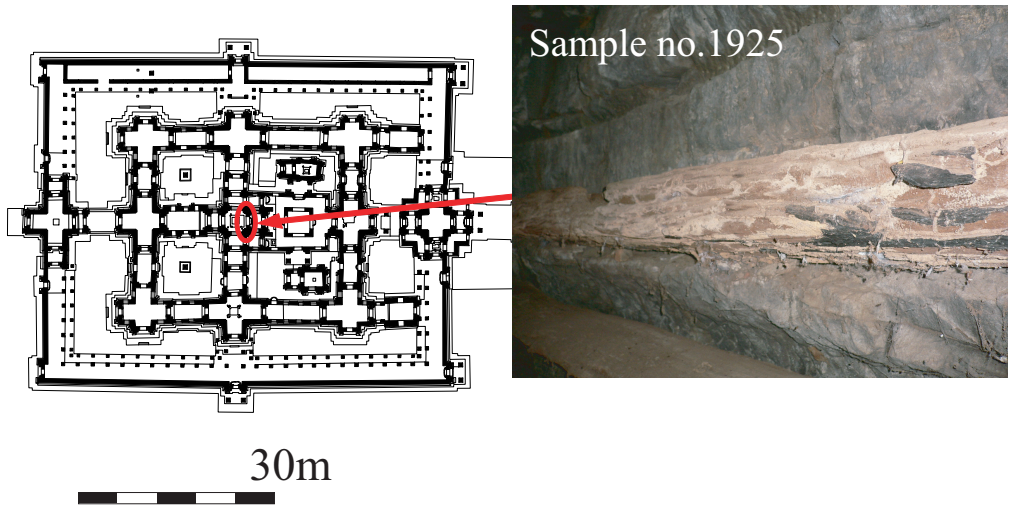

Figure 6 Location of sample 1925, a ceiling bracket in the central tower in Banteay Kdei 
The ${ }^{14} \mathrm{C}$ date for the ceiling bracket at the central tower shows a range of AD 1030-1210 (2 $\left.\sigma\right)$. Because Banteay Kdei was built at the end of the 12th century to the early 13th century, there is a high probability that the ceiling bracket is original.

\section{Bayon}

Like Banteay Kdei, Bayon was constructed from the end of 12th century to the early 13th century. Wood remains only inside the central tower (Figure 7). Wood samples were collected from the head frames of doorways (samples 1921 and 1922), a crossbeam with pivot hole (sample 1923), and wood embedded in the inner wall (sample 1924), which was decorated on 1 side.

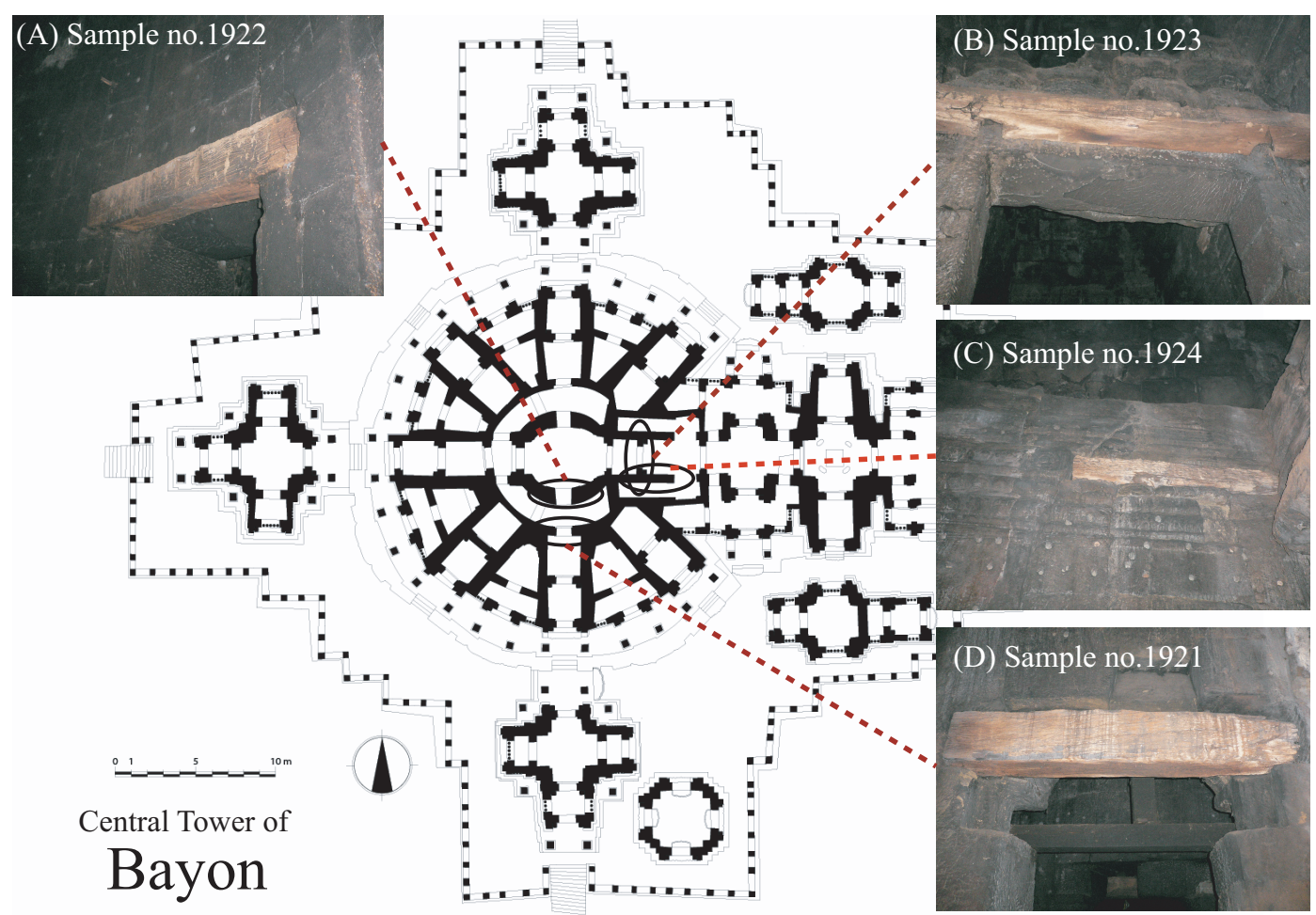

Figure 7 Location of wood samples in the central tower of Bayon: (A) a head frame in the inner doorway; (B) a crossbeam with pivot hole in the middle doorway; (C) a horizontal wood in the inner wall; and (D) a head frame in the inner door.

Samples 1923 and 1924 gave ${ }^{14} \mathrm{C}$ age ranges (2 $\left.\sigma\right)$ of AD 1040-1220 and 1040-1210, respectively. These are fairly concordant with the construction period of Bayon (end of 12th to early 13th century). Therefore, it is highly possible they are original. ${ }^{14} \mathrm{C}$ dates for samples 1921 and 1922 range from AD 1180-1265 and 1180-1270, respectively. These results do not contradict the construction age of Bayon. However, there is a possibility they were placed slightly later than the construction of the central tower of Bayon. According to Nishimoto (2000) and Cunin (2007), the wooden beams of samples 1921 and 1922 were added when the northern and the southern doors of the central tower were opened during the Bayon style period. 


\section{Gates of Angkor Thom}

The Gates of Angkor Thom are considered to have been constructed in nearly the same period as the central tower of Bayon (Uchida et al. 2003). Wood remains as tie beams in the North, West, East, and Victory Gates. Wood was sampled from the lower tie beam on the north side (sample 1916, Figure 8) of the West Gate, which was decorated on both sides.

\section{West Gate of Angkor Thom}

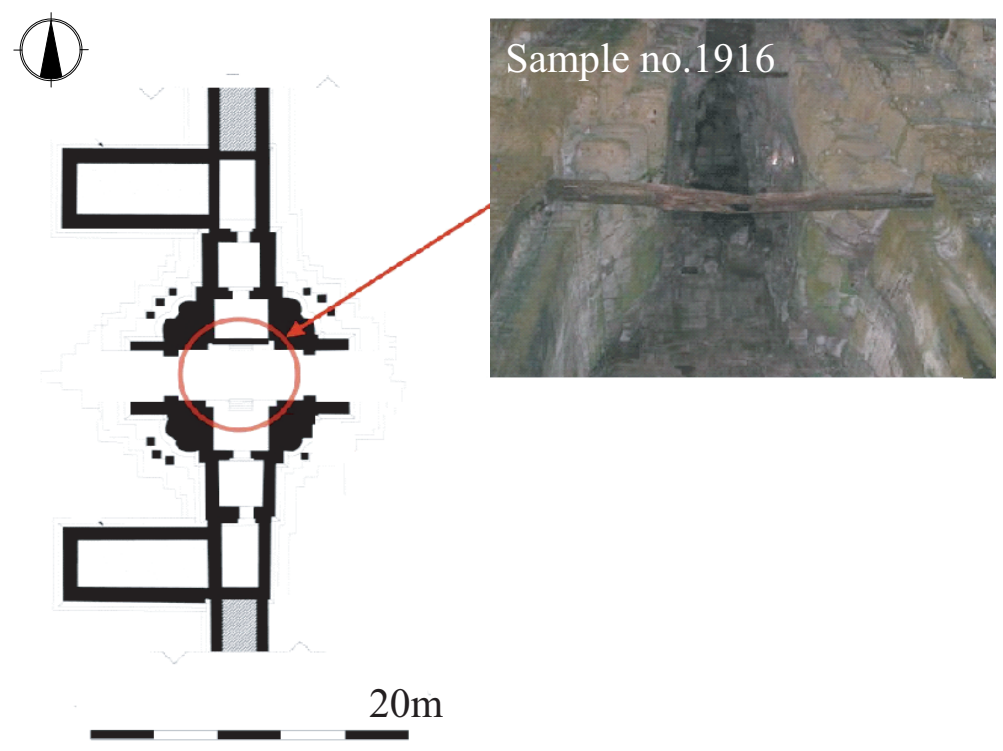

Figure 8 Location of sample 1916, a lower tie beam from the north side of the West Gate of Angkor Thom.

The ${ }^{14} \mathrm{C}$ age for sample 1916 ranges from AD $1170-1260(2 \sigma)$. Construction of the West Gate of Angkor Thom is supposed to have been nearly the same as for the central tower of Bayon; thus, the ${ }^{14} \mathrm{C}$ result does not contradict the construction age of the West Gate of Angkor Thom.

\section{SUMMARY}

${ }^{14} \mathrm{C}$ dating of 15 wood samples collected from 8 monuments of the Angkor complex shows a high probability that the wood samples are original, except for the head frame of a doorway in Baksei Chamkrong, and the ceiling boards of the NW tower and a crossbeam with pivot hole of the SW tower in the Inner Gallery of Angkor Wat. Furthermore, the ${ }^{14} \mathrm{C}$ dating results support the hypothesis that the inner walls under the central tower in North Khleang are an addition from a later period.

\section{ACKNOWLEDGMENTS}

This work was financially supported by a Grant-in-Aid for Scientific Research from the Ministry of Education, Science and Culture of Japan (Project no. 17403001: Uchida) and also by the UNESCO/ Japanese Funds-in-Trust for the Preservation of World Cultural Heritage (Nakagawa). We thank these organizations for financial support. We also thank all members of the Japanese Government Team for Safeguarding Angkor for their helpful comments and encouragement. 


\section{REFERENCES}

Boisselier J. 1952. Běn Mãlả et la chronologie des monument du style d'Ankor Văt. Bulletin de l'École Française d'Extrême-Orient 46(1):187-238. In French.

Bronk Ramsey C. 1995. Radiocarbon calibration and analysis of stratigraphy: the OxCal program. Radiocarbon 37(2):425-30.

Bronk Ramsey C. 2001. Development of the radiocarbon calibration program. Radiocarbon 43(2A):355-63.

Cunin O. 2007. The Bayon: an archaeological and architectural study. In: Clark J, editor. Bayon: New Perspectives. Bangkok: River Books. p 136-229.

Dumarçay J. 1998. The Site of Angkor. New York: Oxford University Press. $72 \mathrm{p}$.

Glaize M. 1944. Les Monuments du Groupe d'Angkor. Saigon: A. Portail. 280 p. In French.

Kobayashi K, Niu E, Itoh S, Yamagata H, Lomtatidze Z, Jorjoliani I, Nakamura K, Fujine H. 2007. The compact ${ }^{14} \mathrm{C}$ AMS facility of Paleo Labo Co., Ltd., Japan. Nuclear Instruments and Methods in Physics Research B 259(1):31-5.

Nishimoto S. 2000. Notes on the building phases of the faces towers on the uppermost terrace at Bayon. In: Fourth Symposium on the Bayon-Final Report. Paris: United Nations Educational, Scientific and Cultural Organization (UNESCO). p 91-7.

Reimer PJ, Baillie MGL, Bard E, Bayliss A, Beck JW, Bertrand CJH, Blackwell PG, Buck CE, Burr GS, Cutler KB, Damon PE, Edwards RL, Fairbanks RG, Friedrich M, Guilderson TP, Hogg AG, Hughen KA,
Kromer B, McCormac G, Manning S, Bronk Ramsey C, Reimer RW, Remmele S, Southon JR, Stuiver M, Talamo S, Taylor FW, van der Plicht J, Weyhenmeyer CE. 2004. IntCal04 terrestrial radiocarbon age calibration, 0-26 cal kyr BP. Radiocarbon 46(3):1029-58.

Uchida E, Ogawa Y, Nakagawa T. 1998. The stone materials of the Angkor monuments, Cambodia - the magnetic susceptibility and the orientation of the bedding plane of the sandstone. Journal of Mineralogy, Petrology and Economic Geology 93(11):411-26.

Uchida E, Cunin O, Shimoda I, Suda C, Nakagawa T. 2003. The construction process of the Angkor monuments elucidated by the magnetic susceptibility of sandstone. Archaeometry 45(2):221-32.

Uchida E, Suda C, Ueno A, Shimoda I, Nakagawa T. 2005. Estimation of the construction period of Prasat Suor Prat in the Angkor monuments, Cambodia, based on the characteristics of its stone materials and the radioactive carbon age of charcoal fragments. Journal of Archaeological Science 32(9):1339-45.

Uchida E, Cunin O, Suda C, Ueno A, Nakagawa T. 2007. Consideration on the construction process and the sandstone quarries during the Angkor period based on the magnetic susceptibility. Journal of Archaeological Science 34(6):924-35.

Zoppi U, Barbetti M, Fletcher R, Hua Q, Chhem RK, Pottier C, Watanasak M. 2004. The contribution of ${ }^{14} \mathrm{C}$ AMS dating to the Greater Angkor archaeological project. Nuclear Instruments and Methods in Physics Research B 223-224:681-5. 